\title{
AGENCY DESIGN IN THE EUROPEAN UNION
}

\section{Herwig C.H. Hofmann*}

This article gives a brief overview of the main features, functions and future perspectives of agencies in the European Union [EU]. It highlights the specific notion of the EU's highly integrated, multi-level legal system as an explanatory factor for the specificities of agency design. The article looks at agencies in the EU through the lens of the structural and procedural arrangements for their independence and their accountability. The article comes to the conclusion that, generally speaking, accountability and independence are defined by and adapted to the position of an agency within the structure of administrative networks implementing EU law and policy. Their raison d'être is usually to coordinate Member State implementing activities rather than taking on these responsibilities themselves.

Cet article présente un bref apercu des caractéristiques principales, des fonctions et des perspectives d'avenir d'agences au sein de l'Union Européenne [UE]. Il met en évidence la notion particulière que les spécificités de la façon dont les agences sont structurées s'expliquent par le fait que le système juridique de l'UE est hautement intégré et à niveaux multiples. L'article examine des agences de l'UE dans la perspective des arrangements structuraux et procéduraux en vue de leur indépendance et de leur obligation de rendre compte. L'article conclut que de façon générale l'obligation de rendre compte et l'indépendance sont définies par, et adaptées à, la position d'une agence dans le cadre des réseaux administratifs qui appliquent la loi et les politiques de l'EU. Leur raison d'être est généralement de coordonner les activités d'application des États Membres plutôt que d'être chargées elles-mêmes de ces responsabilités.

\section{INTRODUCTION}

The "agencification" of the European Union $[\mathrm{EU}]$ is continuing with full force. Currently, one might be forgiven for the impression that there is hardly a policy initiative in the EU which would not suggest the creation of an EU agency or the upgrading of an existing EU administrative structure to become an agency. The EU administrative landscape, as EU public law in general, remains radically experimentalist, transforming itself continuously, albeit often below the radar of the non-specialist public. The question therefore arises, what these agencies are, what they can do and to whom they are accountable? This paper gives a brief overview of the main features, functions and future perspectives of agencies in the EU. It highlights the specific notion of the EU's highly integrated, multi-level legal system as an explanatory factor for the specificities of agency design.

* Herwig C.H. Hofmann is Professor of European and Transnational Public Law and founding

Director of the Centre for European Law at the University of Luxembourg, Luxembourg. 


\section{POWERS, DESIGN AND CONSTITUTIONAL POSITION}

The latest major amendment to the constitutional charter of the EU, the Treaty of Lisbon, changes only very little with regard to the legal framework for agencies in the EU. One of the very few differences is that agency activity is now explicitly subject to judicial review. ${ }^{1}$ But with only little case law on the essential aspects of agency design and agency functions in the EU, much is open in the political and scholarly legal debate on the possible structure and rights of EU agencies.

Three major aspects have an impact on the structure and the competencies of agencies as well as on their independence and accountability. One aspect arises from the notion of de-central implementation of EU law. Member States are empowered and obliged to implement $\mathrm{EU}$ law by means of national legislation and administration. Uniform legal enforcement in such de-central implementation requires a high level of coordination between the Member States and their administrative agencies. This coordinating role has in the past typically been played by comitology committees advising and supervising the European Commission (hereinafter referred to as the Commission). In an increasing amount of policy areas, this coordinating role is being undertaken by agencies of varying forms and designs. In a comparative perspective, however, one needs to add that European agencies are marked by generally limited functions when it comes to administrative rule-making. This distinguishes them from their counterparts in some Member States of the EU and also from those in other legal systems such as the US. European agencies may be authorised to make single-case decisions (adjudication) or to coordinate networks of regulators and to inform decision-makers, but they only exceptionally, and to a degree indirectly, engage in rule-making.

Second, the design and functioning of EU agencies are influenced by their scope of activity and purpose. Some are designed to advise the Member States and the EU institutions by providing information and by fulfilling a coordinating role for regulatory activity. Some actually prepare decisions to be ultimately taken by the Commission. Other agencies are designed to make implementation decisions in a given policy field with external effect vis-à-vis individuals. Finally, some are designed as hybrid entities which execute a certain policy or project in partnership with private parties and investors. ${ }^{2}$

A third aspect which has an impact on the nature of an agency is its accountability mechanisms through administrative supervision, including: method of agency reporting to the Commission; auditing by the Court of Auditors; political supervision, (which includes aspects of accountability to the EU legislative bodies) typically

1 See the second sentence of the first paragraph of Article 263 Treaty on the Functioning of the European Union (TFEU, stating that the Court of Justice of the European Union "shall also review the legality of acts of bodies, offices or agencies of the Union intended to produce legal effects vis-à-vis third parties." This is almost the only mention of an EU agency in the entire Treaty. The case law of the Court of Justice had been further advanced than that. In Soglema the now General Court had held that agency acts were subject to judicial review (Case T-411/06 Sogelma v EAR [2008] ECR II-2771, para. 36). This was highly appropriate in view of Article 47 of the EU's Charter of Fundamental Rights (which has now entered into binding force) explicitly granting the right to an effective remedy.

2 See e.g. the agency established to the run the experimental fusion-energy project ITER - Council Decision No 2007/198/Euratom of 27 March 2007 establishing the European Joint Undertaking for ITER, OJ 2007 L 90/58 and Council Regulation No 1908/2006 of 19 December 2006 laying down the rules of the participation of undertakings, research centres and universities, OJ 2007 L 54/4. 
exercised by the European Parliament [EP] or the Council by means of budgetary powers, powers to nominate high ranking agency personnel, reporting duties and other methods; and finally, judicial review.

A widely accepted definition of EU agencies describes them as decentralised forms of administration that integrate national administrative bodies into the operations of the EU agencies by providing structures for co-operation between the supranational and national levels and between the national authorities. ${ }^{3}$ Yet, this definition helps paper over the fact that the structure and scope of activities differ considerably among EU agencies.

\section{A. Function, Classification and Organisation of Agencies}

When looking at the role of agencies in the EU legal system, one should not forget that, generally, implementation of EU policies takes place in cooperation with and as coordination of national and EU actors in the context of administrative networks. The need for creating EU agencies, which like in many legal systems have no direct constitutional basis, can be explained by the specific conditions for implementing EU law within a network structure. Basically, as is re-iterated in Article 291 (1) Treaty on the Functioning of the European Union [TFEU], the "Member States shall adopt all measures of national law necessary to implement legally binding Union acts." In fact, most of the institutional features of agencies and many of their accountability mechanisms can be understood best as being oriented towards undertaking this networking function. At first sight, this seems to run counter to the generally received wisdom of EU administration being undertaken either at the EU or the Member State levels. One of the main reasons for this development of implementing EU policies in networks of EU and Member State actors may lie in the relatively small administrative capacities of the EU in relation to its duties. ${ }^{4}$

In this context, there is a continuously growing gap between the prolific creation of agencies in the EU and conferral of powers on them on the one hand, and their recognition in EU primary constitutional Treaty law on the other hand. ${ }^{5}$ As Dehousse writes, "European integration is an unprecedented attempt to build a form of continental order without recreating the hierarchical power structure of states," ${ }^{\prime 6}$ but warns that "as those who have been following the situation know, the creation of European agencies was a fairly haphazard development." In its 2002 Communication $^{8}$ the Commission saw the key reason for the establishment of

3 E. Chiti, "Decentralisation and Integration into the Community Administrations: A New Perspective on European Agencies" (2004) 10 Eur LJ 402 at 423-431; S. Griller \& A. Orator, "Everything under control? The way forward for European agencies in the footsteps of the Meroni doctrine" (2010) 35 Eur L Rev 3.

4 H. Kassim, "The European Administration: Between Europeanization and Domestication" in J. Hayward \& A. Menon eds, Governing Europe (Oxford: Oxford University Press, 2003) 139 at 151.

5 D. Curtin, "Delegation to Non-Majoritarian Agencies and Emerging Practices of Public Accountability" in D. Geradin, R. Munoz \& N. Petit eds, Regulation through agencies in the EU, (Cheltenham: Elgar, 2005) 88; D. Fischer-Appelt, Agenturen der Europäschen Gemeinschaft (Berlin: Duncker und Humblot, 1999) at 87-117.

$6 \quad$ R. Dehousse, "Delegation of Powers in the EU: The Need for a Multi-principals Model" (2008) 31 Western European Politics, 789 at 793.

$7 \quad$ Ibid at 790 .

8 Commission of the European Communities "Communication from the Commission - The operating framework for the European Regulatory Agencies” Brussels COM (2002) 718 final. 
agencies as "the independence of their technical and/or scientific assessments." Their main advantage is therefore that "their decisions are based on purely technical evaluations of very high quality and are not influenced by political or contingent considerations." In that sense, agencies help to create "Europe-wide epistemic communities whose technical truths transcend intergovernmental politics." However, agencies are also established as a more covert form of European integration at a time when "direct routes to further integration of the Union are blocked." "Therefore, the rise of agencies as organisational forms in the EU goes hand in hand with the emergence of the constitutional principle of subsidiarity. Subsidiarity in the EU requires, simply stated, that action be taken on the European level only where a shared objective can actually be better achieved by action of the EU than by its Member States. The stated goal is to maintain government functions on a level as close as possible to its citizens. ${ }^{12}$ In reality, observance of the principle of subsidiarity in the EU has required the development of a system of decentralised yet cooperative administrative structures since Member States generally insist they are better placed to implement a policy. The cooperative structures then develop, for example, through information exchange, joint warning systems, coordinated remedies for arising problems and a wealth of similar systems, all of which have been functions of EU agencies. Agencies thus aid in satisfying the need for uniformity in the implementation of Union law, while at the same time providing a form of decentralised implementation. ${ }^{13}$ The aim of European agencies is therefore predominantly "to run networks of national administrations which come into play in the implementation of Community policies." 14

These network coordination functions of agencies, their more limited decisionmaking power and their linkage with national administrations, distinguish EU agencies from their US counterparts. ${ }^{15}$ EU agencies are, however, closing the gap. Some agencies have genuine decision-making powers. The Office for the Harmonisation of the Internal Market [OHIM] is empowered to make legally binding decisions on applications to register Community trademarks and Community designs. Similarly, the Community Plant Variety Office [CPVO] has the competence to adopt legally binding decisions in relation to applications for the registration of plant variety rights. So far, the furthest reaching delegations in force, have been given to the European Air Safety Agency [EASA]. It has been entitled to adopt non-binding "guidance material." Given that this power is exercised in the context of the empowerment to issue individual decisions, such soft law "guidance" comes close to

Ibid at 5 .

10 M. Shapiro, "The problems of independent agencies in the United States and the European Union" (1997) 4 Journal of European Public Policy 276 at 282.

11 Ibid at 281

12 Article 5 (3) TEU states that "Under the principle of subsidiarity, in areas which do not fall within its exclusive competence, the Union shall act only if and in so far as the objectives of the proposed action cannot be sufficiently achieved by the Member States, either at central level or at regional and local level, but can rather, by reason of the scale or effects of the proposed action, be better achieved at Union level."

13 R. Dehousse, "Regulation by networks in the European Community: the role of European agencies" (1997) 4 Journal of European Public Policy 246 at 257.

14 Ibid at 255

15 Chiti, supra note 3 at 429. 
hard law regulatory powers. The EASA also has quasi regulatory powers when advising the Commission on the rules to be adopted to implement the air safety regulation. ${ }^{16}$ These quasi-regulatory powers arise from the fact that the technical part of its opinions, in particular, the part dealing with the construction, design and operation of aircraft, cannot be altered by the Commission without prior collaboration with the Agency. In this role, EASA establishes administrative rules both for its internal administrative procedures as well as administrative rules to be applied by the Member States. ${ }^{18}$ The resulting internal "rulemaking procedures" of the agency include provisions for the establishment of a rulemaking programme, formal initiation of the process, the drafting of the rules, participation and consultation procedures (including consequent review of comments) and, finally, the rules regarding publication and entry into force of the agency guidelines. ${ }^{19}$ In many ways these rule-making procedures can be regarded as models for rule-making procedures by agencies. The approach chosen in the EASA legislation provides for procedures akin to the US approach of "notice and comment procedures" used in most administrative rule-making procedures by US agencies.

In view of these functions, classifications of EU agencies, despite the necessary generalisations, are an attempt to improve transparency and to streamline control, accountability and supervision of the exercise of public powers by EU agencies. I will not present various past attempts at classification but instead try to categorise agencies by their legal basis - i.e. the origin of delegation distinguishing between vertical and horizontal delegation of powers to agencies.

"Vertical" delegation takes place at the EU level between the Commission and an agency. In this case, the Commission, after having being delegated the powers to implement a policy in a legislative act, will "sub-delegate" this power to an EU agency. Most cases of vertical delegation can be found in what in EU terms is generally referred to as executive agencies. Executive agencies are those which the Commission has set up by executive decision to administer Union programmes in accordance with Council Regulation 58/2003. They can be entrusted with managing

16 Similarly, the European railway agency is entrusted in the field of railway safety with drafting common safety methods and common safety targets to be adopted by the Commission and binding on the Member States (See Art. 6 of Directive 2004/49/EC of the European Parliament and of the Council of 29 April 2004 on safety on the Community's railways and amending Council

Directive 95/18/EC on the licensing of railway undertakings and Directive 2001/14/EC on the allocation of railway infrastructure capacity and the levying of charges for the use of railway infrastructure and safety certification (Railway Safety Directive), OJ 2004 L 220/16). In addition, the agency has the task of drafting and proposing a harmonised format for both safety certificates and for applications for them (see Art. 7 of Regulation (EC) 881/2004 of the European Parliament and the Council of 29 April 2004 establishing a European Railway Agency (Agency Regulation), OJ 2004 L $164 / 1$, as amended).

17 Articles 12 b and 13 b of Regulation (EC) 1592/2002 of the European Parliament and of the Council of 15 July 2002 on common rules in the field of civil aviation and establishing a European Aviation Safety Agency, OJ 2002 L 240/1.

18 Articles 14, 43 of Regulation 1592/2002, [2002] OJ L 240/1 and EASA MB/7/03 (Final) of 27.06.2003, European Aviation Safety Agency, Decision of the Management Board concerning the procedure to be applied by the agency for the issuing of Opinions, Certification Specifications and Guidance Material ("Rulemaking Procedure", online: EASA <www.easa.eu.int>).

19 Articles 14, 43 of Regulation 1592/2002, [2002] OJ L 240/1. 
any tasks required to implement a Community Union programme, but not given "discretionary powers in translating political choices into action." 20

From this, one can distinguish "horizontal" delegation which takes place directly in EU legislation creating an agency or empowering an EU agency with certain implementing tasks which would otherwise by default reside with the Member States. ${ }^{21}$ Cases of horizontal delegation are often undertaken in the context of what is generally, in a somewhat lazy shorthand, referred to as "regulatory" agencies. This terminology however does not imply that an agency has necessarily rule-making powers as is the case of many US agencies or agencies of EU member states such as is the case under Swedish administrative law. ${ }^{22}$ Unlike executive agencies, in the case of regulatory agencies, the legislative act or a Treaty provision directly creating an agency provides it with delegated powers. Legal disputes to the extent of powers which may be delegated or which have been delegated under these various legal bases are ripe. ${ }^{23} \mathrm{EU}$ regulatory agencies can be sub-categorised in different ways, for example, according to the functions they perform. It is thus possible, with the Commission working paper of $2008,{ }^{24}$ to distinguish agencies adopting individual decisions, ${ }^{25}$ providing direct assistance to the Commission and the Member States' administrations (through technical know-how, scientific expertise, inspection reports and other means), ${ }^{26}$ agencies in charge of operational activities (often with far reaching powers in the definition of the content and the reach of the operations, as well as the means employed to achieve them), ${ }^{27}$ and finally agencies responsible for coordination of networks of national regulators (which generally also support these, by supplying technical and scientific expertise as well as collecting information). ${ }^{28}$ Some agencies perform several of the mentioned functions. This list is far from complete, however. For example in the area of research, special partnership bodies have been created as

20 Article 6(1) of Council Regulation (EC) 58/2003 of 19 December 2002 laying down the statute for executive agencies to be entrusted with certain tasks in the management of Community programmes, OJ 2003 L $11 / 1$.

21 Article 4 (3) TEU and Article 291 (1) TFEU.

22 The majority of agencies which are often labelled "regulatory" are established by EU legislation properly so named on the legal basis of either a general provision such as Articles 114 or 352 TFEU or on a policy specific legal basis such as Article 187 TFEU for research, and other legal basis.

23 Especially Article 114 TFEU, which is now the legal basis for many new agencies, has been subject to much dispute. See for an illustration the disputes underlying the cases C-66/04 UK v Parliament and Council (smoke flavourings) [2005] ECR I-10553; Case C-217/04 UK v Parliament and Council (ENIS A) [2006] ECR I-3771, discussed in greater detail by K. Bradley, "Comitology and the Courts: tales of the unexpected" in H.C.H. Hofmann \& A. Türk, eds, EU Administrative Governance, (Cheltenham: Elgar, 2006) 417; and H.C.H. Hofmann, "Which Limits? Control of Powers in an Integrated Legal System" in C. Barnard and O. Odudu eds, The Outer Limits of EU Law (Cambridge: Cambridge University Press, 2008) 45.

24 COM (2008) 135 final.

25 These include inter alia the European Trade Mark Office [OHIM], the European Air Safety Agency [EASA] and the chemical registration agency of the REACH regulation [ECHA].

26 These include inter alia the European Marine Safety Agency [EMSA], the European Food Safety Agency [EFSA], the European Railway Agency [ERA].

27 For example quite a few agencies are in this category such as inter alia the European border safety agency [FRONTEX], the former Council agencies EUROJUST, EUROPOL and CEPOL.

28 For e.g. the European Network Information Safety Agency [ENISA], the European Centre for Disease Control [ECDC], the European Fundamental Rights Agency [FRA] and the European Institute for Gender Equality. 
mixed public and private law bodies. These have been created to include third party and private financing into certain high-level research projects such as the international fusion energy project ITER, SESAR for air traffic management, or the European Institute of Innovation and Technology.

The organisation of agencies follows this basic distinction into vertical and horizontal delegation. Generally speaking, executive agencies which benefit from vertical (sub-) delegation by the Commission have a standardised structure under Regulation 58/2003 which leaves leeway only for small adjustments. That Regulation establishes that executive agencies are managed by a director ${ }^{29}$ and a steering committee. ${ }^{30}$ Anticipatory supervision of the executive agencies by means of vertical hierarchies include the authorisation of the detailed work plan and the draft operating budget of an executive agency, which must be submitted by its steering committee to the Commission annually. ${ }^{31}$ Ex post supervision takes place through the Commission's right to review and overrule agency decisions in specific cases. ${ }^{32}$

Regulatory agencies are directly created and empowered by legislation. They are generally governed by a management board (sometimes also called administrative board or council) typically with one representative from each Member State, some minority (often non-voting) representatives of the Commission, and sometimes other (non-voting) members such as representatives of the social partners, academic experts, industry representatives and other stakeholders. The management board is responsible for appointments within the agency, the budget, work programming, and evaluations. In some instances the Commission can object to the proposed work programme. $^{33}$ The management board usually appoints the director of an agency (sometimes called president) on the basis of a Commission and in some cases a Council proposal often after a hearing by the European Parliament. ${ }^{34}$ Generally, a candidate needs to be independent and have the necessary skills for the position. ${ }^{35}$

29 The Commission appoints the agency's director, generally for a period of four years. The director externally represents the agency, is responsible for its management and performance. She or he is responsible for the agency's budget, prepares the reports and is in charge of employment contracts (Articles 10, 11 of Regulation 58/2003).

30 The steering committee consists of five members appointed by the Commission for two years (Art. 8 of Regulation 58/2003). This committee adopts the agency's annual work program (including objectives and performance indicators) and the budget on the basis of a draft by the director and after approval by the Commission. It also submits an annual activity report together with financial and management information to the Commission.

31 Articles 7-12 of Council Regulation (EC) 58/2003 of 19 December 202 laying down the statute of executive agencies Art. 13 (2), OJ 2003 L 11/1.

32 Article 22 et seq. of Council Regulation (EC) 58/2003 of 19 December 202 laying down the statute of executive agencies Art. 13 (2), OJ 2003 L 11/1.

33 In this case the agency has to re-examine its programme and can adopt the programme, possibly amended, usually only with a two-thirds majority on the management board, which either must include the Commission representative's vote, or be based on unanimity among the Member States' representatives. This is the case in the context of the EMSA, the ERA and the Community Fisheries Control Agency [CFCA].

34 See e.g. Art. 26(1) of Regulation (EC) 178/2002 of the European Parliament and the Council of 28 January 2002 laying down the general principles and requirements of food law, establishing the European Food Safety Authority and laying down procedures in matters of food safety, OJ $2002 \mathrm{~L}$ $31 / 1$

35 See e.g. Art. 15(1) and 16 of Regulation (EC) 1406/2002 of the European Parliament and the Council of 27 June 2002 establishing a European Maritime Safety Agency, OJ 2002 L 208/1, as amended. 
The director is accountable to the management board and charged with the preparation and execution of its decisions, reporting and the day-to-day running of the agency, including staff matters. Given the technicality of many agency dossiers, they generally also contain scientific committees. Their appointment varies from designation by the management board ${ }^{36}$ to nomination by the Member States ${ }^{37}$ or a mixture of both. ${ }^{38}$

There is little in the way of standardised, supervisory methodology between the various forms of regulatory agencies. However, the one big exception is in regard to financial regulation. ${ }^{39}$ The EU financial regulation contains essential rules concerning agencies' establishment plan, the creation of what is known as an agencies' framework financial regulation, the consolidation of the agencies' accounts with those of the Commission, and the discharge by the European Parliament [EP]. In addition, the framework financial regulation lays down common rules governing the establishment and implementation of their budget, including control aspects. Budgetary discharge is granted by the EP.

\section{B. Delegation of Powers}

In all modern legal systems, effective government requires the allocation of broad, general and often discretionary powers to administrative actors. ${ }^{40}$ The same is true in the context of the EU although EU constitutional law does not explicitly regulate delegation to EU agencies. The only explicit mentioning of agencies in the EU's constitutional basis takes place within the English language version of the first paragraph of Article 263 TFEU dealing with the annulment procedure before the European Court of Justice.

Nevertheless, case law on delegation was already established in the early days of European integration by the limitation on the powers of European agencies deriving originally from the Meroni ${ }^{\text {t1 }}$ ruling, in which the Court considered as unlawful the delegation of discretionary powers to agencies and restricted such delegation to clearly defined powers. In Meroni, the Court was reviewing the possibility of (what then was the High Authority and what later became) the European Commission to confer implementing powers on a private body. In the terminology introduced in this article, it would have been a case of vertical delegation of powers. In Meroni, the Court held that no more powers could be delegated by the Commission than had legally been granted and that such delegation must be explicit. ${ }^{22}$ The power of the Commission in Article 53 of the Treaty establishing the European Coal and Steel

36 As is the case with the European Environmental Agency [EEA] and the EFSA.

37 As is the case with the European Medical Agency [EMEA] and EUROFOUND.

38 As is the case with the European Monitoring Centre for Drugs and Drug Addiction [EMCDDA].

39 Council Regulation (EC, Euratom) 1605/2002 of 25 June 2002 as amended. See also Proposal for a Council Regulation on the Financial Regulation Applicable to the General Budget of the EC, COM (2000) 461 final, in Amended Proposal for a Council Regulation on the Financial Regulation Applicable to the General Budget of the EC, COM (2001) 691.

40 S.A. Shapiro, R.M. Murphy, "Eight Things Americans Cannot Figure Out About Controlling Administrative Power", (2009) 61 Admin L Rev 5 at 6; more generally for e.g. J. D. Huber \& C. R. Shipan, Deliberate Discretion? The Institutional Foundations of Bureaucratic Autonomy (Cambridge: Cambridge University Press, 2002).

41 Cases 9 and 10/56 Meroni v High Authority [1957/58] ECR English Special Edition 133.

42 Ibid at 150, 151. 
Community [ECSC, which is no longer in force] to authorise or decide on the financial arrangements, however, "gives it the right to entrust certain powers to such bodies subject to conditions to be determined by it and subject to its supervision." ${ }^{* 3}$ Delegation is thus possible when it "involves clearly defined executive powers" and when their exercise can "be subject to strict review in the light of objective criteria determined by the delegating authority." On the other hand, where delegation involves "a wide margin of discretion which may, according to the use which is made of it, make possible the execution of actual economic policy" such delegation can not take place through the type of vertical delegation provided in the case. ${ }^{4}$ As reason for establishing this distinction, the ECJ refers to the principle of institutional balance - the EU terminology for the concept of the relative separation of powers. This reference to a general principle of law, one might argue, makes it unlikely that the Meroni ruling ought to be limited to the specific context of the ECSC Treaty $y^{45}$ and should be considered as being applicable also within the legal system of the Lisbon regime. ${ }^{46}$ One might, on the other hand, equally argue that the institutional balance in the context of the ECSC was sufficiently specific as to not follow the notion of Meroni too strictly in the very different context of the EU under the Treaty of Lisbon. As Schneider argues, the EU's legal system is based on a more open legal framework explicitly recognising delegation to agencies. ${ }^{47}$ Also, Vos finds that delegation of broader powers to agencies nowadays ought not to fall afoul of the Meroni doctrine, as the EU's institutional balance could be protected "by a reinforcement or rebalancing of the existing institutions and constitutional guarantees for decisionmaking.,

However, as Dehousse reminds us, not only legal but also political considerations play a role for the more narrowly defined mandate of European agencies. ${ }^{49}$ In particular, the Commission seems to be anxious not to let the undoubted help that agencies provide in reducing its administrative overload result in a loss of its administrative authority and control. In reality, some agencies have gained quite considerable influence over the decision-making process, perhaps already stretching the Meroni doctrine to its limits, as was illustrated above with the example of the European Air Safety Agency [EASA]. This is not only the case where agencies have been entrusted with the adoption of binding decisions, ${ }^{50}$ but also where they play an

43 Ibid at 151.

$44 \quad$ Ibid at 152.

45 However, see R. Dehousse, "Misfits: EU Law and the Transformation of European Governance" in C. Joerges \& R. Dehousse eds, Good Governance in Europe's Integrated Market (Oxford: Oxford University Press, 2002) 207 at 221. Dehousse argues that its general framework sufficiently distinguishes the EC Treaty from the regime prevalent under the previous ECSC Treaty, in which the High Authority exercised important regulatory powers. In particular, in contrast to the enforcement of EC law by national authorities, Art. 53 ECSC entrusted its application to the High Authority itself.

46 K. Lenaerts, "Regulating the Regulatory Process: 'Delegation of Powers' in the European Community” (1993) 18 Eur L Rev 23 at 41.

47 J.P. Schneider, "EU Agencies and the Meroni Doctrine" (2008) 61 Admin L Rev 29 at 38.

48 E. Vos, "Reforming the European Commission: What Role to Play for EU Agencies?" (2000) 37 CML Rev. 1113 at 1123.

49 Dehousse, supra note 45 at 223.

50 See Council Regulation (EC) 2100/94 of 27 July 1994 on Community plant variety rights, OJ 1994 L 227/1; Council Regulation (EC) 207/2009 of 26 February 2009 on the Community trade mark 
essential part in the decision-making process such as the European Medicines Agency [EMEA] which is in charge of authorisation and supervision of medical products. ${ }^{51}$ EMEA has been given the task to deliver scientific opinions on applications for the authorisation of pharmaceutical products. Even though its opinions are not binding on the Commission, which takes the final decision in accordance with the applicable comitology procedure, it has been argued that "the EMEA's opinion appears to condition substantially the discretion of the Commission in taking the final decision", in particular as the Commission is obliged to "systematically rubber-stamp EMEA recommendations.",53

More recent case-law has to a certain degree loosened the strictures of the Meroni style non-delegation doctrine. In Scbräder v CPVO, ${ }^{54}$ the applicant challenged a decision of the Board of Appeal of an EU agency, the Community Plant Variety Office [CPVO]. In its review of the agency decision, the General Court applied only limited judicial review, explicitly because of the "discretion" the agency enjoyed. ${ }^{5.5}$ This statement is remarkable, since without any reference to Meroni, the Court finds that an agency, such as the CPVO, can be entrusted with the exercise of administrative decisions subject only to marginal judicial review, a standard of review reserved for discretionary decisions. In Commission v Germany of March 2010 the Grand Chamber of the ECJ held that powers could be delegated to an agency (in this case EU law provided for delegation to national agencies) if democratic oversight of an independent agency was sufficiently protected. That was the case if first, parliament controlled the appointment of senior management of the agency as well as if second, the agency was required to submit regular public reports to the parliament. ${ }^{56}$ Although it is not entirely clear to date whether this dictum is equally applicable to the EU itself, the case paints a more delegation-friendly picture of the current case law allowing for more independence of agencies than is generally regarded to be the case under the Meroni doctrine.

As an interim result, the debate on the importance of the early statements of the ECJ in a much changed legal environment is vigorous. It appears that the seminal Meroni case, the non-delegation doctrine is based on the idea that delegation of wide discretion, which would impede the institutional balance as defined by the Treaties, is not possible. Wide discretion is a notion which refers, in the definition of the ECJ, to quasi-legislative powers which means establishing the core elements of a policy for implementation. That leaves the possibility of far reaching delegation, even rulemaking powers if limited by legislative guidance and exercised by institutional

(codified version), OJ 2009 L 78/1; Regulation (EC) 1592/2002 of the European Parliament and the Council of 15 July 2002 on common rules in the field of civil aviation and establishing a European Aviation Safety Agency, OJ 2002 L 240/1.

51 Regulation (EC) 726/2004 of the European Parliament and of the Council of 31 March 2004 laying down Community procedures for the authorisation and supervision of medicinal products for human and veterinary use and establishing a European Medicines Agency, OJ 2004 L 136/1. See E. Chiti, "The Emergence of a Community Administration: the Case of European Agencies", (2000) 37 CML Rev 37309 at 336.

53 Dehousse, supra note 45 at 223. See also Vos, supra note 48 at 1132.

54 Case T-187/06 Schräder v Community Plant Variety Office (CPVO) [2008] ECR II-3151, confirmed on appeal in Case C-38/09 P Schräder v CPVO [2010] ECR I-nyr of 15 April 2010.

55 Ibid at para 63.

56 Case C-518/07 Commission v Germany of 9 March 2010, [2010] ECR I-nyr, at paras 42-46. 
supervision. It is within this logic that delegation of powers to agencies is growing. The Courts seem to be accepting this increasingly. Agencies, however, exercise their powers in cooperation with, rather than in isolation from other EU institutions, national and international bodies due to the complexities of the integrated system of administration in the EU.

\section{ACCOUNTABILITY AND INDEPENDENCE IN THE CONTEXT OF NETWORK COORDINATION}

The conditions for independence and accountability of EU agencies are governed by the specific context of integrated administration. EU agencies face a predicament. Although they are supposed to act with executive neutrality they also are responsible to the political bodies of the EU with respect to budgets, work-plans and nominations of leading personnel as well as to Member States through the Council. ${ }^{57}$ Everson therefore points out some major factors of independence and accountability of agencies: Agencies are created and receive delegation of certain powers to exercise them by bundling expertise and technical know-how. This expertise is the main source of agency independence. This substantive independence is curtailed by mostly procedural rules to ensure accountability to politically responsible institutions of the EU. Independence is to be exercised in the context of integration of various administrative structures from the European and the Member State levels that deal with the implementation of EU policies.

\section{A. Accountability}

With respect to EU agencies, both the political dimension of accountability, in ensuring that the political will prevails, and its legal dimension, in aiming to ensure compliance with the law, are designed to be established by ex ante and by ex post accountability mechanisms. Ex ante accountability mechanisms of agencies broadly allow for the defining of tasks and for imposing conditions for carrying them out, including the choice of personnel entrusted with the tasks and the allocation of the budget to do so. Ex post mechanisms provide inter alia for possible demands to justify actions taken, as well as rewards for compliance or sanctions for non-compliance with the tasks defined ex ante. ${ }^{58}$

In EU law, the supervision of agencies appears to rely significantly on anticipatory elements, mainly through the right to nominate key personnel within an agency. In executive agencies, this right is tightly linked to the Commission's hierarchic administrative control, allowing it, for example, to nominate the members of the steering committees and the director of the agency. In regulatory agencies, this form of $e x$ ante supervision has a more political dimension, due to the distribution of the nomination rights and hearing provisions amongst the Council, the EP and the Commission. For example, the members of the management boards are generally nominated by the Council on the basis of Member State representation. The election

57 M. Everson, “Agencies: the dark hour of the executive?” in H. Hofmann \& A. Türk eds, Legal Challenges in EU Administrative Law (Cheltenham: Elgar, 2009) 116.

58 M. Bovens, "Analysing and Assessing Accountability: A conceptual framework" (2007) 13 Eur LJ 447. The ECJ links this notion with the requirement to guarantee an institutional balance, stating in Case 70/88 Parliament v Council [1990] ECR I-2041, para. 22 that "[o]bservance of the institutional balance $(. .$.$) requires that it should be possible to penalize any breach of that rule which may occur."$ 
of the director of a regulatory agency usually takes place by the management board on the basis of a proposal from the Commission or the Council. In some cases, the election takes place after a hearing of the EP.

Anticipatory supervision also is exercised through the authorisation of work programmes and budgets. Again, with respect to executive agencies, this control is often in the form of hierarchic administrative supervision by the Commission. With respect to regulatory agencies, the political aspect of these supervision tools becomes more important. Also with regulatory agencies, there are aspects of administrative supervision in certain cases. Such supervision may exist, for example, where the Commission has the right to object to proposed work programmes. ${ }^{59}$ But generally, the director establishing the work and the financial planning of an agency is responsible to the management board, the majority of which is comprised of Member State representatives.

Ex post supervision takes place through administrative, political and judicial supervision. On the level of administrative supervision, executive agencies have reporting duties to the Commission through reports submitted by their steering committees. The reporting duties of regulatory agencies allow the Member States and the political and administrative institutions of the Union to exert pressure on the agency. Agency regulations usually provide that an annual report has to be forwarded to the Member States, the European Parliament, the Council and the Commission. ${ }^{60}$ Certain agencies specify that the director will address the agency's activities in a general report to the European Parliament. ${ }^{61}$ Some agency regulations even provide that the European Parliament or the Council can require the director to participate in a hearing on any subject related to the agency's activities. ${ }^{62}$ Finally, exceptionally, some agency statutes provide that agency actions can be referred to the Commission for a review of legality or subject to internal review within the agency itself.

Supervision of agency activity takes place internally in cases in which agencies with decision-making powers have mechanisms for legality review in the form of an internal appeal. In those cases, following the internal appeal procedure is a precondition for the admissibility of judicial review through an appeal to the General

59 As is the case in the context of the EMSA and the ERA.

60 See e.g. Art. 6(9) of Regulation (EC) 460/2004 of the European Parliament and the Council of 10 March 2004 establishing a European Network and Information Security Agency [ENISA], OJ 2004 L 77/1, as amended; Art. 25(2)(b) of Regulation (EC) 881/2004 of the European Parliament and of the Council of 29 April 2004 establishing a European railway agency (ERA), OJ 2004 L 220/3, as amended and many more.

61 See e.g. Art. 32 of Regulation (EC) 881/2004 of the European Parliament and of the Council of 29 April 2004 establishing an ERA, OJ 2004 L 220/3, as amended.

62 See e.g. Art. 32 of Regulation (EC) 881/2004 of the European Parliament and of the Council of 29 April 2004 establishing a European railway agency (ERA), OJ 2004 L 220/3, as amended; Art. 15(6) of Council Regulation (EC) 168/2007 of 15 February 2007 establishing a European Union Agency for Fundamental Rights [EFA], OJ 2007 L 53/1.

63 See e.g. Art. 18 of Council Regulation (EEC) 337/75 of the Council of 10 February 1975 establishing a European Centre for the Development of Vocational Training (CDVT), OJ 1975 L 39/1, as amended; Art. 22 of Council Regulation (EEC) 1365/75 of 26 May 1975 on the creation of a European Foundation for the improvement of living and working conditions, OJ 1975 L 139/1, as amended; Art. 22 of Council Regulation (EC) 2062/94 of 18 July 1994 establishing a European Agency for Safety and Health at Work, OJ 1994 L 216/1; Art. 28 of Regulation (EC) 851/2004 of the European Parliament and the Council of 21 April 2004 establishing a European centre for disease prevention and control, OJ 2004 L 142/1. 
Court. ${ }^{64}$ In all other cases, judicial review can be brought against agency decisions by parties directly or indirectly affected by a decision or by a Member State or EU institution under Article 263 TFEU.

Accountability is also linked to transparency. Transparency is in this context understood not in the more narrow sense of giving the right to access to documents (irrespective of the essential importance of that right for holding an agency accountable) but in the broader sense of improving the allocation of responsibility for decision-making. The latter is in many ways a pre-condition for exercising ex ante and ex post accountability measures. In this respect, the much criticised European Agency of the Management of Operational Cooperation at the External Borders [FRONTEX] may serve as an example for how the creation of an agency may increase transparency about EU activity. FRONTEX was established by Council regulation replacing much of the previously existing fragmentary and opaque structures that were attached to the Council in one form or another, for example the Common Unit for external border practitioners [SCIFA] that was a Council Working Party. ${ }^{65}$ The fact that FRONTEX has been given quite far reaching operational powers in patrolling and securing the EU's external borders as well as its empowerment to enter into international operational cooperation, however, contains its own specific challenges for transparency with respect to the allocation of responsibilities.

\section{B. Independence}

Independence of agencies may arise from various factors including inter alia the expertise of an agency and its relation to the regulated interests, an agency's organisational structure and its procedural provisions, as well as the position of the agency within the network administration of the EU. Independence is a relative concept. Independence can be freedom from influence by specific stakeholders in a matter - for example EU institutions, Member State governments or private parties. Being independent from the influence of one group of stakeholders, however, might in reality arise on the basis of strong influence or even dependence on others. Independence can also manifest itself in forms of financial independence or absence of control or supervision. Independence from certain external influences may also arise from practical aspects, for example the unique expertise that an agency has

64 See Art. 58-65 of Council Regulation (EC) 207/2009 of 26 February 2009 on the Community trade mark (codified version) (OHIM), OJ 2009 L 78/; Art. 67-73 of Council Regulation (EC) 2100/94 of 27 July 1994 on Community plant variety rights (CPVO), OJ 1994 L 227/1; Art. 31-41 and Art. 11 of Regulation (EC) 1592/2002 of the European Parliament and the Council of 15 July 2002 on common rules in the field of civil aviation and establishing a European Aviation Safety Agency (EASA), OJ 2002 L 240/1.

65 Curtin, supra note 5 at 99. FRONTEX is an EU agency with a legal personality and a certain operational autonomy. It has its own budget which is in part financed by the EU, in part by those Schengen Member States which are not members of the EU such as Liechtenstein, Iceland, Norway and Switzerland. FRONTEX is governed by its management board, which consists of operational heads of national border control authorities and representatives of the European Commission. The management board verifies the execution of the agency's budget and adopts internal financial rules. It further adopts working and mission procedures for inter alia the so called Rapid Border Intervention Teams [RABIT] which are mixed units from member State border guards jointly pursuing missions at the EU's external borders. The management board also is in charge of appointing the Executive Director and the deputy of the agency. 
accumulated allowing it, in reality, to set its agenda and remain unchallenged in its decisions.

Expertise underlines the notion of decision-making based on the scientific as opposed to political influence over a certain decision-outcome. Expertise can be integrated into the agency by means of its permanent personnel as well as with respect to the integration of expert committees within the agency. Expertise and with it, independence of an agency, can however also be enhanced by participation of the regulated interest and other private parties who have an interest in the matter. For example, the EASA Regulation which stipulates that the procedures for the development of opinions, certification specifications and guidance material shall involve not only expertise of national aviation regulatory authorities, but also involve experts from "the relevant interested parties" and shall ensure that the agency publishes documents and "consults widely interested parties, according to a timetable and a procedure which includes an obligation on the Agency to make a written response to the consultation process." ${ }^{\prime 66}$

These procedural provisions strengthening the expertise of an agency go hand in hand with other elements of independence. Agency independence relies to a large extent on the fact that accountability and supervisory mechanisms are often based on ex ante nomination of personnel and ex post reporting and discharging mechanisms. For example, unlike executive agencies, for regulatory agencies hardly any substantive elements exist in the form of directions or guidance as to the nature of individual decision-making other than the above mentioned forms of requiring work programmes to be authorised in certain cases. This choice towards procedural forms of supervision has a strong influence on ensuring independence of European agencies.

Independence of agencies is, it appears from this discussion, relative. Executive agencies are explicitly auxiliary bodies to support the Commission, over which the Commission wields almost exclusive control. On the other hand, EU regulatory agency structures are a mirror of the competing interests involved in implementation of EU law and the conflicts of whether the European or the Member State levels should implement a policy and to what degree. The result is a structure in which the representatives of various interests have their role to play. It should be noted that such a multiplicity of actors involved in the delegation and supervision of delegated powers may result in a certain degree of strengthening the independence of the agency. ${ }^{67}$ Confronted with conflicting positions by several principals, agents may feel encouraged to apply their own best judgement to a problem. Establishing overview from various principals without the possibility of any single one blocking activity in case of conflicts with other principals, gives the agent large amounts of freedom.

The question of independence is also relative to the issue of the influences from which independence is sought. ${ }^{68}$ Is the goal to achieve independence of an agency from political influence expressed by the Commission or the European Parliament, from specific Member State interests or from the interests of a specific industry or

66 Article 52 (1) (c) of Regulation No 216/2008 of the EP and the Council on the common rules in the field of aviation and establishing the European Aviation Safety Agency, OJ 2008 L 79/1.

67 For a detailed discussion, see Vos, supra note 48 at 1125-33.

68 For a more in depth discussion see E. Chiti, “An Important Part of the EU's Institutional Machinery: Features, Problems and Perspectives of European Agencies” (2009) 46 CML Rev 1395 at 1399. 
consumer lobby? The organisational structure which would be most appropriate to achieve this independence will differ accordingly.

\section{REFLECTIONS FOR THE FUTURE}

The factors leading to accountability and independence of EU agencies are both procedural and substantive. Not surprisingly, they differ as to the policy area and the legal basis of the agency. Generally speaking, accountability and independence are defined by the position of an agency within the administrative networks implementing EU law and policy. Agencies are actors which are created to navigate the difficult territory of implementation of EU law in the grey-zone between EU and Member State competencies. They are created and receive delegation of powers under EU law. Their raison d'etre is usually to coordinate Member State implementing activities rather than taking on these responsibilities themselves.

The independence of an agency can increase with its accountability to multiple principals - namely, EU institutions as well as Member States. Next to this, even in the absence of clearly defined decision-making powers, a factor increasing an agency's independence is the amount of specific and unique expertise it can unite within its services. Such expertise and with it the independence of an agency is generally enhanced when the agency has access to information and participation of interested parties and stakeholders in the policy. The broader the spectrum of interests taken into account, and the more institutionalised and transparent the participation, the more independence the agency may gain. This arises from being able to gather a unique amount of information and knowledge about a specific topic which supports the already existing expertise-based legitimacy within an agency. Such participatory legitimacy, as one might call it, can be regarded a case of increased input-legitimacy into decision-making. Good input and well designed procedure will generally generate a bigger chance of proper outcome, which in turn generally dissuades Courts and political actors from intervening in the substantive choices of an agency.

Further independence arises, as the case of several agencies shows, from the possibility to conduct internal self-control of decisions. This sort of control is oriented towards legality and reasonableness of a decision and may generally raise the quality and legitimacy of decision-making procedures. Reflecting on the features leading to the independence of agencies in the EU is of course directly linked to aspects of accountability. Accountability can be strengthened in the context of reducing the amount of principals. EU executive agencies, for example, are nearly entirely controlled and responsible to the Commission. This makes them accountable but also much less independent vis-à-vis the political orientation of the Commission. Accountability will also be strengthened by the combination of ex ante and ex post supervision tools. Such supervision tools will include judicial review. Judicial review will have to be developed with the increasing powers conferred on agencies. Finally, accountability will be strengthened not only by control and supervision mechanisms but also simply by increasing transparency. EU administrative law, due to its network character, is in permanent evolution. The structures and responsibilities are generally rather opaque to outside observers. Clear distribution and descriptions of responsibilities and decision-making structures are a key ingredient to enhancing accountability of the exercise of public powers. 